\title{
Badanie wpływu ciśnienia i temperatury na proces wytrącania parafin w ropie naftowej
}

\begin{abstract}
W publikacji rozważono tematykę wpływu ciśnienia i temperatury na wytrącanie się osadów parafinowych z płynów złożowych. Scharakteryzowano ważniejsze metody badawcze służące do określania temperatury depozycji stałej fazy parafinowej (Wax Apperance Temperature - WAT). Wykorzystując odpowiednio zmodyfikowaną aparaturę PVT, wyznaczono temperaturę początku wytrącania się parafiny (WAT), z uwzględnieniem wpływu ciśnienia i rozpuszczonego gazu w próbce ropy. Wykonane badania pozwoliły na określenie warunków równowagowych (w układzie ciśnienie-temperatura), przy których ma miejsce depozycja stałej fazy parafinowej. Na podstawie przeprowadzonych eksperymentów wyznaczona została granica rozdzielająca obszar parafinowy (występowanie parafin w fazie stałej) od obszaru bez parafiny. Dokładne określenie stref (w zakresie ciśnienia i temperatury) powstawania osadów parafinowych jest istotnym zagadnieniem w planowaniu wydobycia i transportu węglowodorów. Pozwala to uniknąć trudności w utrzymaniu przepływu wynikających z obecności parafinowego osadu oraz kosztów związanych z jego usuwaniem.
\end{abstract}

Słowa kluczowe: parafiny, WAT, depozycja stałej fazy parafinowej.

\section{Investigation of the influence of pressure and temperature on paraffin wax deposition in crude oil}

In this paper, the issue of pressure and temperature influence on paraffin wax deposition in reservoir fluids was raised. Typical research methods for determining wax appearance temperature (WAT) were briefly characterized. The wax appearance temperature was studied taking into account, pressure and the amount of gas dissolved in oil samples using a suitably modified PVT apparatus. Investigations performed allowed to determine the equilibrium conditions (of PT) at which the deposition of paraffin waxes occurs. On the basis of the conducted research, there was a zone determined with wax deposition hazard and another one without a risk of solid wax precipitation. The precise determination of wax precipitation zones is a significant issue in the planning of recovery and transport of hydrocarbons. It allows to avoid flow assurance problems caused by solid wax deposits, as well as the cost generated for their elimination.

Key words: paraffins, WAT, paraffin wax deposition.

\section{Wprowadzenie do zjawisk formowania się osadów parafinowych}

Proces depozycji parafiny z płynów złożowych, szczególnie w głębokich odwiertach, jest niejednokrotnie przyczyną wstrzymania wydobycia ropy i gazu. Przy określaniu sposobów zapobiegania wytrącaniu parafiny z płynów złożowych w czasie ich eksploatacji niezbędne jest ustalenie warunków depozycji stałej fazy parafinowej (Wax Appearance Temperature - WAT). Znajomość temperatury początku wytrącania parafin jest konieczna dla określenia optymalnej dla danych warunków metody przeciwdziałania powstawaniu wy- trąceń parafinowych, blokujących przepływ mediów złożowych. Pozwala to przede wszystkim na określenie głębokości w odwiercie eksploatacyjnym, na której można się spodziewać zagrożenia związanego z wytrącaniem się wosków parafinowych. Szczególnie ważne jest to w przypadku nowo dowierconych złóż, gdzie nieznany potencjał parafinowania może już na etapie testu produkcyjnego stać się przyczyną znacznych strat finansowych związanych z usunięciem powstałych korków parafinowych. 


\section{Ogólna charakterystyka parafin}

Mianem parafin określa się grupę węglowodorów nasyconych, przy czym istnieją istotne różnice $\mathrm{w}$ interpretacji składu tej grupy w zależności od kontekstu:

- w chemii organicznej termin ten odnosi się do alifatycznych węglowodorów nasyconych (homologów metanu) o ogólnym wzorze $\mathrm{C}_{\mathrm{n}} \mathrm{H}_{2 \mathrm{n}+2}$, posiadających od 1 do 61 atomów węgla w cząsteczce, występujących w fazie gazowej, ciekłej oraz stałej;

- w żargonie naftowym parafinami nazywane są mieszaniny n-alkanów, izoalkanów i cykloalkanów w fazie stałej. Do tej grupy zaliczyć możemy również woski, osady zawierające 17 lub więcej atomów węgla w cząsteczce, wytrącające się z mediów złożowych w procesie ich wydobycia.

Parafinowanie to wytrącanie się z ropy naftowej osadów na ściankach armatury napowierzchniowej. Proces ten generuje znaczne trudności i zagrożenia podczas eksploatacji, transportu oraz procesów przeróbki węglowodorów. Problem dotyczy nie tylko złóż ropnych i kondensatowych, ale rów- nież gazowych $[10,14]$. Wytrącająca się parafina może osadzać się na ściankach orurowania, zmniejszając przepływ. Niejednokrotnie prowadzi to do całkowitego wstrzymania wydobycia na skutek zaczopowania rurek wydobywczych, żerdzi pompowych, jak również rurociągów napowierzchniowych. Parafinowanie przyczynia się do generowania znacznych strat finansowych związanych ze zmniejszeniem wydobycia, zwiększeniem zapotrzebowania energii na przetłaczanie oraz koniecznością wykonywania kosztownych zabiegów serwisowych $[1,13,16]$.

Wyróżniamy dwa rodzaje wosków wytrącających się z płynów złożowych:

- woski makrokrystaliczne składające się głównie z n-alkanów o masie cząsteczkowej od 300 do 600, krystalizujące w formie płaskich/płytkowych struktur,

- woski mikrokrystaliczne lub amorficzne tworzone głównie przez izo- i cykloalkany o masach czasteczkowych w zakresie od 300 do 2500, krystalizujące w formie małych igiełkowych struktur $[6,15]$.

\section{Zjawisko wytrącania się parafiny z płynów złożowych}

\section{Wpływ ciśnienia i temperatury}

W warunkach złożowych parafina pozostaje w stanie równowagi z innymi rozpuszczalnymi składnikami płynu złożowego. W wyniku zaburzenia istniejącej równowagi, na skutek zmian temperatury lub ciśnienia (które powodują zmniejszenie rozpuszczalności wosków), może dojść do wytrącenia parafiny z mediów złożowych i jej osadzania na ściankach rur (fotografia 1). Pojedyncze kryształy parafiny mają tendencje do dyspersji. Agregacja cząstek i ich depozycja w formie osadu następuje dopiero, gdy ich ilość jest odpowiednio duża lub gdy współwystępują inne składniki ułatwiające gromadzenie się kryształków (np. asfalteny, produkty korozji, części ilaste, drobiny skalne).

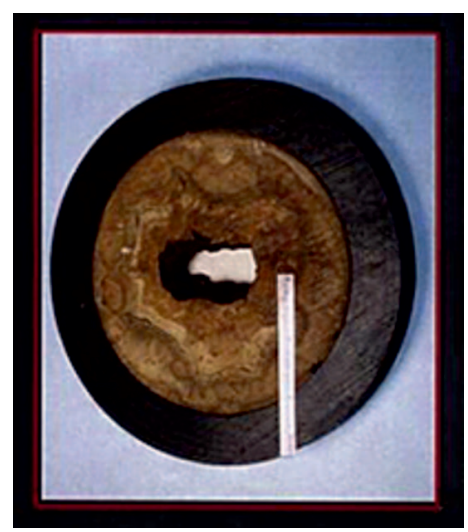

Fot. 1. Przykład rurociągu zaczopowanego na skutek depozycji parafiny na ściankach [22]
Czynnik temperaturowy odgrywa kluczową rolę w wytrącaniu wosków, gdyż rozpuszczalność parafin w płynach złożowych zmniejsza się wraz ze spadkiem temperatury. Szczególnie narażone na parafinowanie są instalacje wydobywcze i transportowe znajdujące się na wysokich szerokościach geograficznych oraz pod powierzchnią mórz i oceanów (ze względu na panujące tam niskie temperatury). Silną zależność wytrącania wosków od temperatury doskonale ukazuje przykładowy diagram fazowy, na którym granica rozdzielająca obszary występowania faz stałej i płynnej jest niemal pionowa (rysunek 1).

Na utworzenie fazy stałej składają się dwa odrębne etapy: nukleacja i swobodny wzrost kryształów. Kiedy temperatura płynu złożowego spada do tzw. temperatury początku wytrącania parafiny (WAT), cząsteczki wosków łączą się ze sobą, tworząc „klastry” - wielocząsteczkowe zlepy nazywane zarodkami. Zarodki kontynuują proces łączenia się w większe aglomeraty, do momentu osiągnięcia wielkości krytycznej gwarantującej stabilność. Faza tworzenia zarodków nazywana jest nukleacją. Jeżeli temperatura utrzymuje się poniżej WAT, następuje faza wzrostu kryształów, w której cząsteczki łączą się w struktury blaszkowe lub płytkowe [7].

Temperatura, w której wszystkie kryształy parafin na powrót całkowicie rozpuszczają się w płynie złożowym podczas jego ogrzewania, nazywana jest temperaturą rozpuszczenia parafin (Wax Dissolution Temperature - WDT). 
Jest ona wyższa niż temperatura WAT [17]. Ważnym parametrem wpływającym na depozycję jest szybkość ochładzania się płynu złożowego. Podczas szybkiego schładzania powstają kryształy o mniejszych wymiarach i w większej ilości, tworząc luźną i porowatą strukturę wypełnioną ropą. Przy wolniejszym schładzaniu proces powstawania kryształów jest bardziej jednostajny. Tworzą one wówczas struktury bardziej regularne i upakowane, które zajmują mniejszą objętość.

Ciśnienie ma pośredni wpływ na wytrącanie się parafin. Spadek ciśnienia powoduje zmniejszenie rozpuszczalności gazu w ropie i jego przejście z fazy stałej do gazowej. Skutkuje to spadkiem rozpuszczalności parafin i ich wytrącaniem, co wizualnie objawia się zmętnieniem ropy. Temperaturę, w której zachodzi zmętnienie, określa się mianem temperatury zmętnienia (Cloud Point Temperature - CPT). Jest ona równoważna temperaturze WAT [7, 13, 19].

\section{Wpływ wielkości przepływu}

Ilość wytrącającej się parafiny jest zależna od rodzaju i wielkości przepływu. W przypadku przepływu laminarnego wytrącanie zwiększa się wraz ze wzrostem wielkości przepływu, natomiast w przepływie turbulentnym wpływ dyspersji ścinającej powoduje spadek intensywności depozycji parafin. Wielkość przepływu ma również wpływ na strukturę

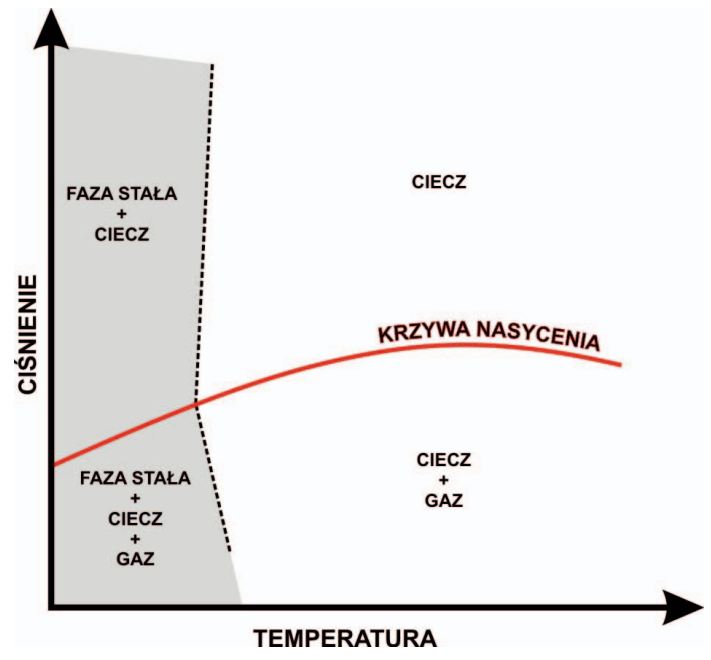

Rys. 1. Przykład typowego diagramu fazowego z oznaczoną strefą wytrącania się osadów parafinowych [12, 18, 19]

wytrącanych kryształów, która podczas większych wydajności staje się twardsza i bardziej zwarta, tym samym trudniejsza do usunięcia.

Zbyt niski przepływ sprzyja wytrącaniu się parafin, gdyż zwiększa on czas przebywania cząsteczek w rurach wydobywczych. Powoduje to większe straty ciepła i obniżenie temperatury ropy, czego konsekwencją jest wzmaganie wytrącania i depozycji parafin [13].

\section{Przegląd metod badawczych do określania temperatury WAT}

Temperatura WAT, odnosząca się do pierwszych oznak wytrącania parafiny, jest najważniejszym parametrem określającym podatność płynów złożowych na depozycje osadów parafiny. Wiele lat badań prowadzonych w tym zakresie zaowocowało opracowaniem szeregu metod badawczych mających na celu jak najdokładniejsze określenie temperatury WAT.

\section{Metoda ,zimnego palca”}

Polega ona na umieszczeniu w próbce ropy (odgazowanej i podgrzanej powyżej WAT) metalowego walca z czujnikiem temperatury. Walec jest stopniowo ochładzany i gdy temperatura spadnie poniżej WAT, rozpoczyna się osadzanie parafiny na jego powierzchni. Metoda ta obarczona jest błędem, gdyż zaobserwowanie parafiny możliwe jest dopiero, gdy utworzy ona odpowiednio grubą powłokę $[2,13]$.

\section{Metoda ASTM Standard D-2500}

Metoda ta (oraz późniejsza jej modyfikacja - D3117) opiera się na inspekcji wizualnej oznak zmętnienia ropy - próbki umieszczonej w szklanym cylindrze o średnicy 1,2 cala. Cylinder z ropą wkłada się do łaźni chłodzącej. Spadek temperatury próbki kontrolowany jest poprzez umieszczony w cylindrze termometr. Chłodzenie przeprowadza się z jednostaj- nym spadkiem temperatury i kontynuuje do momentu pojawienia się oznak zmętnienia. Metoda ta obarczona jest błędami związanymi z bezwładnością termometru oraz brakiem mieszania próbki. Ma ona zastosowanie jedynie dla przejrzystych rop lekkich, w których można zaobserwować zmętnienie $[4,8,13]$.

Modyfikacja ASTM Standard D3117 polega na użyciu mniejszej średnicy cylindra, tj. 0,8 cala. Dzięki mniejszej średnicy grubość filmu tworzonego przez ciecz jest zredukowana, co rozjaśnia obserwowaną próbkę i pozwala na lepszą obserwację pojawienia się zmętnienia [9].

\section{Metoda optycznego mikroskopu polaryzacyjnego - CPM (Cross Polarized Microscope)}

W metodzie CPM zastosowanie mikroskopu znacząco zwiększa możliwość detekcji kryształów wosków o małych rozmiarach. Dodatkowo użycie skrzyżowanych polaryzatorów powiększa kontrast między fazą stałą kryształów parafiny a fazą ciekłą ropy (fotografia 2). Efekt ten powstaje, gdyż obiekty krystaliczne (takie jak kryształy wosków) potrafią obracać spolaryzowaną wiązkę świetlną, co pozwala jej na przeniknięcie przez ustawiony prostopadle drugi pryzmat nikola $[8,13,21]$. 


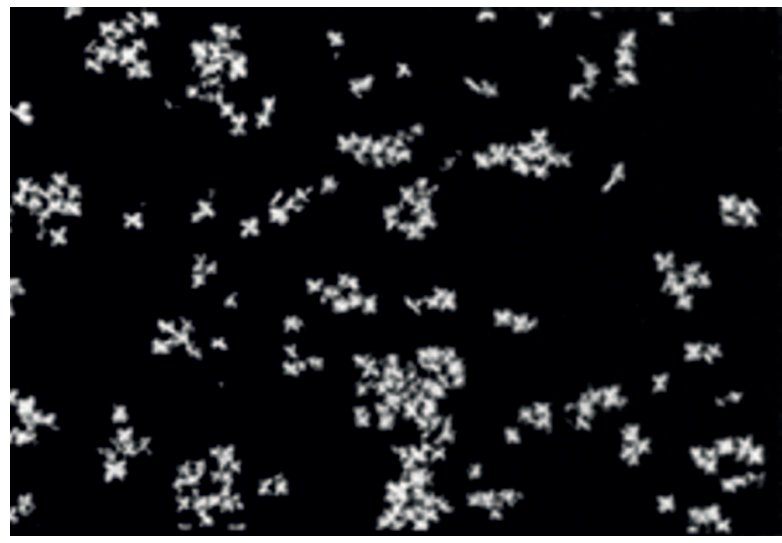

Fot. 2. Mikrofotografia kryształków parafiny (białe drobinki) pod mikroskopem polaryzacyjnym [21]

\section{Metoda furierowskiej spektroskopii w podczerwieni-}

\section{FT-IR (Fourier Transform Infrared Spectroscopy)}

Techniki pomiaru WAT metodą FT-IR opierają się na wyraźnym zróżnicowaniu $\mathrm{w}$ absorbancji promieniowania podczerwonego (IR) przez ciekłą ropę w porównaniu z parafiną w fazie stałej. Węglowodory o dłuższych łańcuchach selektywnie absorbują promieniowanie IR o długości fali $720 \mathrm{~cm}^{-1}$, wzbudzając przy tym drgania wahadłowe w łańcuchu węglowodorowym. Absorbcja powodowana przez węglowodory o dłuższych łańcuchach oznaczana jest jako $\mathrm{A}_{720}$. Parafiny mające strukturę krystaliczną rozdzielają pasmo absorbcji $720 \mathrm{~cm}^{-1}$ na dwa pasma o długościach fal: 730 i $722 \mathrm{~cm}^{-1}$. W celu korelacji ilości parafiny w próbce wyznacza się intensywność absorbancji, która jest zsumowaną powierzchnią poniżej linii widma absorbcji. Śledząc intensywność absorbancji w czasie obniżania temperatury próbki, wyznacza się WAT w punkcie nagłego zwiększenia intensywności (rysunek 2).

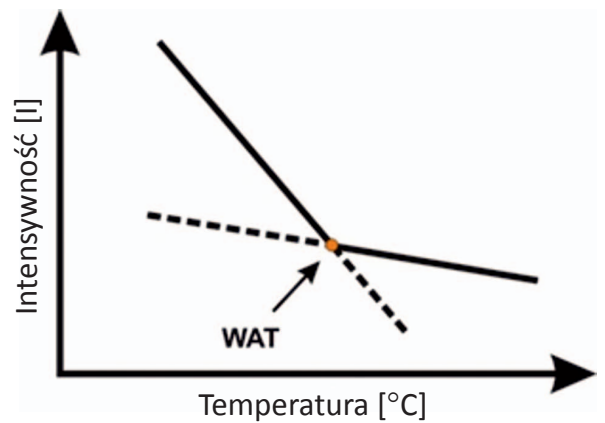

Rys. 2. Wykres zależności intensywności absorbancji od temperatury przedstawiający nagły wzrost intensywności odnoszący się do temperatury WAT [8]

\section{Metoda termiczna różnicowego kalorymetru skaningowego - DSC (Differrential Scanning Calorimetry)}

Metody termiczne wykorzystują fakt, że precypitacja parafiny zachodzi z wydzielaniem ciepła, natomiast rozpuszczanie powoduje jego absorbcję. Jest to ściśle związane z ciepłem topnienia, które dla parafiny wynosi $155 \pm 8,4$ kJ $/ \mathrm{kg}$. Kalorymetr wychwytuje ciepło uwolnione z próbki podczas krystalizacji, na podstawie którego określa się początek wytrącania parafiny (WAT). Samo schładzanie próbki, bez krystalizacji parafiny, również generuje ciepło, które jest rejestrowane przez kalorymetr. By oddzielić ciepło związane z ochładzaniem próbki od tego, które wydziela się podczas krystalizacji, należy ustalić linię odniesienia (tła). Wyznacza się ją przez połączenie punktów początkowych i końcowych na wykresie zależności wielkości strumienia cieplnego od temperatury. Przecięcie linii odniesienia i stycznej do krawędzi przegięcia (przechodzącej przez punkt przegięcia) określa temperaturę WAT (rysunek 3).

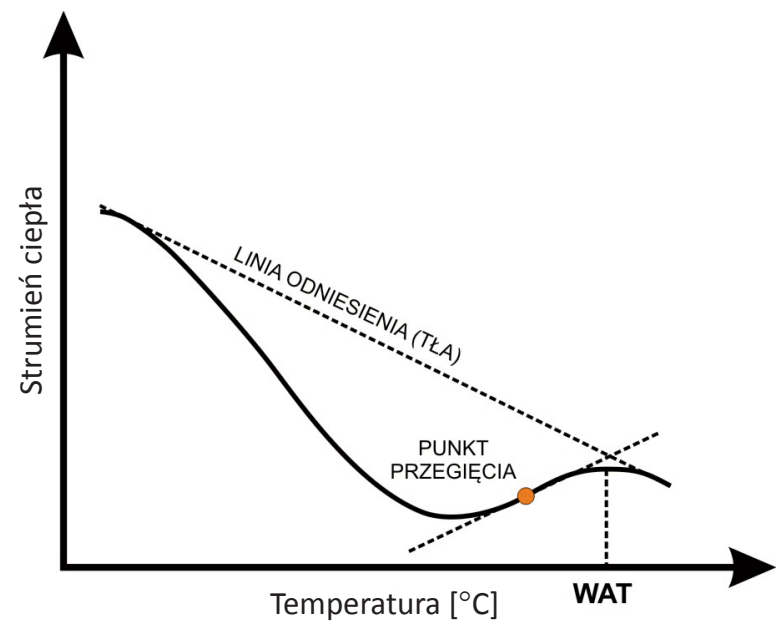

Rys. 3. Zobrazowanie linii odniesienia (tła) oraz punktu przegięcia na przykładowym termogramie DSC; $T$ - temperatura [8]

\section{Metoda fotometryczna}

Metoda ta polega na pomiarach za pomocą fototrody (czujnika fotoelektrycznego) sygnałów fotoelektrycznych wzbudzanych przez urządzenie, przechodzących przez badaną próbkę ropy. Fototroda połączona jest z systemem grzewczo-chłodzącym. W celu zachowania homogeniczności próbki dodatkowo zastosowano system jej mieszania za

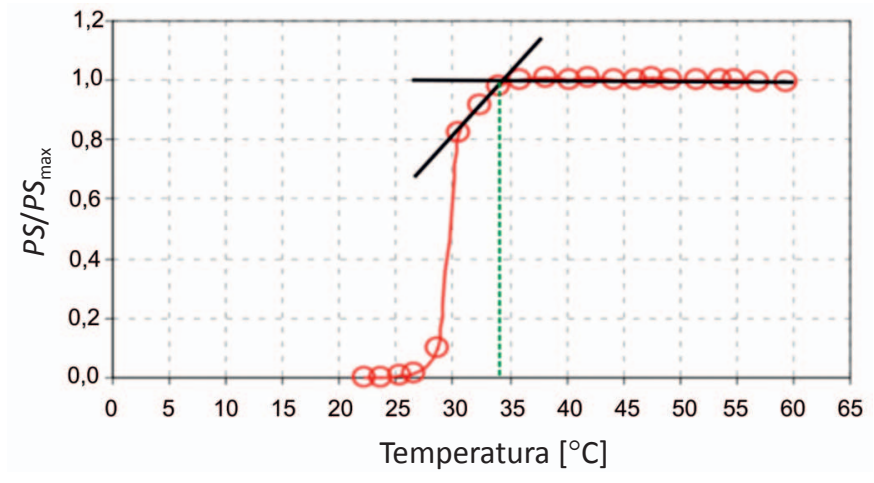

Rys. 4. Określanie temperatury WAT na wykresie stosunku $P S / P S_{\max } \mathrm{w}$ funkcji temperatury [5] 
pomocą drgań. Faza stała wytrącająca się z próbki podczas schładzania powoduje zmianę $\mathrm{w}$ odbieranym sygnale fotoelektrycznym. Podczas schładzania od 60 do $5^{\circ} \mathrm{C}$, przebiegającego z szybkością $0,1^{\circ} \mathrm{C} / \mathrm{min}$, rejestrowane są wartości temperatury oraz sygnału fotoelektrycznego. Na podstawie uzyskanych danych tworzony jest wykres stosunku odebranego sygnału elektrycznego (PS) i jego maksymalnej wartości $\left(P S_{\max }\right) \mathrm{w}$ funkcji temperatury (rysunek 4) [5].

\section{Metoda objętościowego kurczenia parafiny w trakcie krzepnięcia}

Omawiana metoda związana jest ze znaczną różnicą w gęstości pomiędzy fazą ciekłą i fazą stałą kryształów parafiny. Wyróżniamy dwa sposoby określania WAT wykorzystujące zjawisko kurczenia próbki ropy podczas wytrącania się kryształów parafiny:

- w pierwszym temperatura pojawienia się parafiny sygnalizowana jest poprzez gwałtowną zmianę wolumetrycznego współczynnika termicznej ekspansji próbki,

- w drugim obecność fazy stałej jest rozpoznawana dzięki odwirowaniu próbki.

Zarówno w przypadku pierwszego, jak i drugiego sposobu odnotowano trudności z określeniem WAT oraz słabą precyzję pomiarów, co ostatecznie wpłynęło na brak szerszego zastosowania metody w praktyce badawczej $[11,13]$.

\section{Metoda pomiarów oporów filtra w warunkach dynamicznych}

Metoda polega na przetłaczaniu podgrzanej próbki płynu złożowego (odgazowanej ropy lub ropy z rozpuszczonym gazem) przez filtr spiekowy $1 \mu \mathrm{m}$, umieszczony w komorze ciśnieniowej. W komorze obniża się temperaturę, jednocze- śnie rejestrując zmianę oporów przepływu na filtrze za pomocą przetwornika różnicy ciśnień. Wytrącająca się parafina osadza się na filtrze spiekowym, powodując gwałtowne zwiększenie oporów przepływu, co świadczy o osiągnięciu przez próbkę temperatury WAT [13].

\section{Metoda zmiany lepkości w funkcji temperatury}

Podczas krystalizacji zdyspergowane kryształy parafiny tworzą w ropie zawiesinę, która zwiększa jej lepkość. W przypadku cieczy newtonowskich, zgodnie z równaniem Arrheniusa, istnieje liniowa zależność logarytmu lepkości $\mu$ od temperatury $1 / \mathrm{T}$. W momencie pojawienia się zawiesiny ciecz przyjmuje charakter nienewtonowski, a zależność lepkości od temperatury traci charakter liniowy. Zjawisko to wykorzystuje się do identyfikacji temperatury WAT. Charakterystyczne załamanie krzywej lepkości w układzie lepkość-temperatura wyznacza temperaturę początku wytrącania parafiny [13].

\section{Metoda wytrącania frakcjonalnego}

Próbka uprzednio podgrzanej i rozgazowanej ropy (50 g) jest schładzana przez 24 godziny w kriostacie do temperatury nieznacznie przekraczającej spodziewaną temperaturę WAT. Następnie ropę filtruje się przez kolejne 2 godziny, używając filtra z włókna szklanego. Odfiltrowana faza stała jest przepłukiwana acetonem w celu zebrania resztek ropy znajdującej się na jej powierzchni. Pozostała ciecz zostaje użyta do kolejnej precypitacji, którą wykonuje się w następnych krokach, obniżając temperaturę o $3 \div 5^{\circ} \mathrm{C}$. Cała procedura powtarzana jest $4 \div 5$-krotnie, co pozwala na obliczenie ilości parafiny krystalizującej w każdej z badanych temperatur i wykreślenie krzywej wytrącania. Na podstawie krzywej wyznacza się temperaturę WAT [3].

\section{Badania laboratoryjne}

Badania temperatury początku wytrącania parafiny prowadzono z wykorzystaniem bezrtęciowej aparatury PVT do badań właściwości fazowych płynów złożowych. Dla realizacji wymienionych badań zestaw PVT został odpowiednio rozbudowany dodatkowo o szereg połączeń wysokociśnieniowych oraz układ chłodzący (kriostat) służący do utrzymywania zadanej temperatury.

Głównym elementem aparatury przy określaniu początkowych warunków ciśnienia i temperatury wytrącania parafiny był wiskozymetr kapilarny. Modernizacja aparatury polegała na wymontowaniu z łaźni termostatycznej aparatury PVT wiskozymetru i zainstalowaniu go

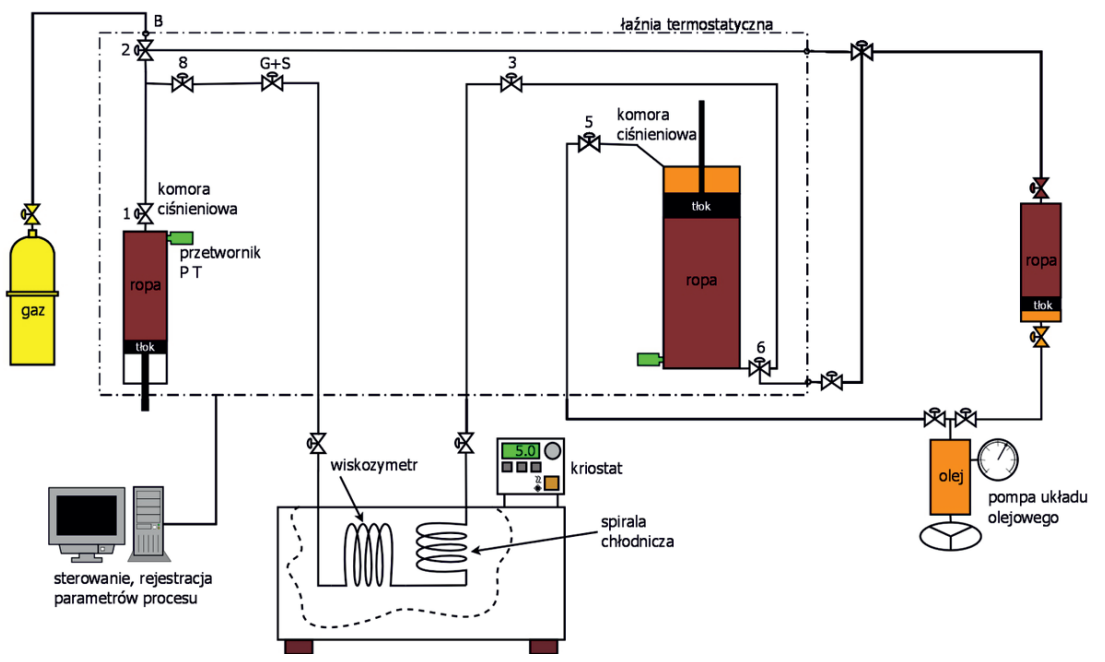

Rys. 5. Aparatura PVT dostosowana do określenia warunków wytrącania stałej fazy parafinowej 
w łaźni kriostatu wypełnionej roztworem glikolu etylenowego. Kriostat dodatkowo pozwalał na precyzyjną regulację temperatury przepływającej próbki płynu złożowego. Zmiana umiejscowienia wiskozymetru umożliwiała utrzymywanie stałej temperatury badanej próbki ropy w komorach badawczych aparatury PVT (powyżej WAT), przy jednoczesnej możliwości obniżania temperatury próbki przepływającej przez wiskozymetr kapilarny (rysunek 5). Takie podejście pozwoliło na wyeliminowanie ryzyka wytrącenia osadu już w komorach ciśnieniowych, co mogłoby spowodować popełnienie znaczących błędów w określeniu warunków wytrącania parafin z ropy. Do badań warunków depozycji stałej fazy parafinowej użyto gazu i ropy pobranych z separatora odwiertu Buszewo-1.

\section{Badania rozpuszczalności gazu separatorowego w ropie separatorowej Buszewo-1}

Badania rozpuszczalności gazu separatorowego w ropie separatorowej Buszewo-1 prowadzono z wykorzystaniem bezrtęciowej aparatury PVT do badań właściwości fazowych płynów złożowych.

W prezentowanych badaniach eksperymentalnych określono rozpuszczalność gazu w ropie separatorowej. Prowadzono je w komorze ciśnieniowej bezrtęciowej aparatury PVT. Komora posadowiona w powietrznej łaźni termostatycznej wyposażona jest w mieszacz magnetyczny, a w swojej górnej części posiada szklany wziernik umożliwiający ciągłą obserwację analizowanej próbki.

Badania rozpuszczalności gazu w ropie separatorowej wykonano w temperaturze $45^{\circ} \mathrm{C}$, tj. wyższej od spodziewanej temperatury WAT.

Uzyskane rezultaty przedstawiono w tablicy 1 . Dzięki prowadzeniu stopniowego odbioru gazu z komory możliwe było wykreślenie zależności rozpuszczalności gazu w ropie w funkcji ciśnienia (rysunek 6).

Uogólniając, można stwierdzić, że w przebadanym zakresie ciśnień i temperatur lepsze rozpuszczanie gazu w ropie zachodzi przy większych wartościach ciśnienia. Przyrost rozpuszczalności wraz ze wzrostem ciśnienia ma charakter liniowy, co doskonale obrazuje rysunek 6 .
Tablica 1 . Wyniki badań rozpuszczalności gazu separatorowego $\mathrm{w}$ ropie: $T=45^{\circ} \mathrm{C}$

\begin{tabular}{|c|c|}
\hline $\begin{array}{c}P \\
{[\text { bar }] \pm 0,5}\end{array}$ & $\begin{array}{c}\text { Rozpuszczalność gazu } \\
{\left[\mathrm{Nm}^{3} / \mathrm{m}^{3}\right] \pm 1}\end{array}$ \\
\hline 400 & 140 \\
\hline 350 & 122 \\
\hline 300 & 106 \\
\hline 250 & 90 \\
\hline 200 & 73 \\
\hline 150 & 57 \\
\hline 100 & 41 \\
\hline 50 & 24 \\
\hline
\end{tabular}

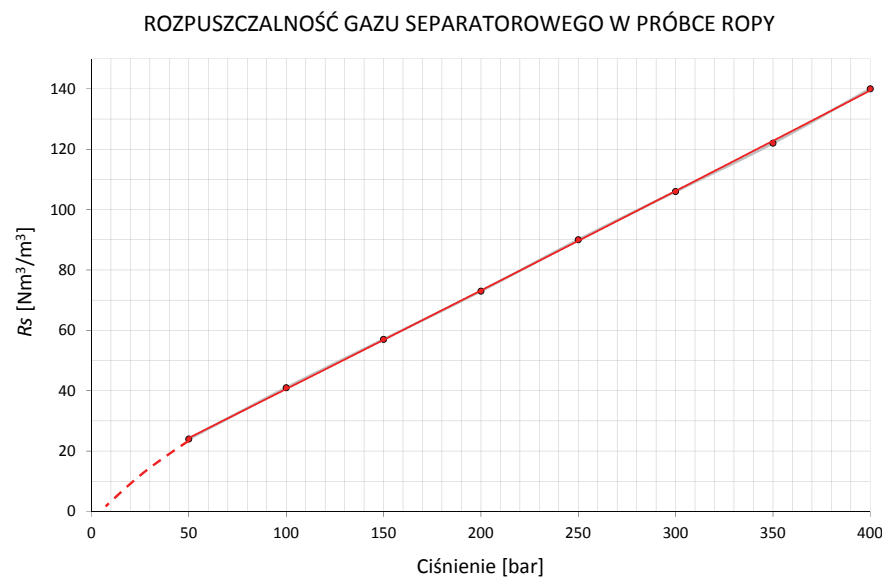

Rys. 6. Rozpuszczalność gazu w próbce ropy separatorowej

\section{Ropa i gaz separatorowy - badanie warunków depozycji stałej fazy parafinowej}

W pierwszej serii badawczej przeprowadzono pięć eksperymentów. Przed każdym badaniem wykonywano rekombinację około $300 \mathrm{~cm}^{3}$ próbki do zadanych warunków ciśnienia w temperaturze $45^{\circ} \mathrm{C}$.

Założono, że pierwszy eksperyment przeprowadzony zostanie dla próbki ropy martwej (nienasyconej gazem). Dla kolejnych badań próbka będzie nasycana gazem w krokach co 50 bar, aż do uzyskania $P_{\text {nas }}=200$ bar.

Na poniższych wykresach zaprezentowano przebieg przeprowadzonych eksperymentów (po dwa do każdego badania). Na pierwszym zobrazowany został wpływ temperatury próbki ropy na opór przepływu. Na drugim wykresie przed- stawiono przyrost oporów przepływu przeliczony na jeden stopień Celsjusza w funkcji temperatury. W obu przypadkach zaznaczona została wartość temperatury WAT.

W tablicy 2 zebrano główne wyniki badań, a na rysunkach 7 i 8 przedstawiono przykładowy przebieg jednego z eksperymentów.

Na rysunku 9 zebrano wyniki pięciu przeprowadzonych eksperymentów. Na podstawie wyznaczonej krzywej łatwo zauważyć, że wraz ze wzrostem ciśnienia nasycenia, a tym samym ilości rozpuszczonego gazu, spada ryzyko wytrącenia osadu parafinowego, ale tylko do ciśnienia nasycenia wynoszącego około 100 barów. Obliczona różnica temperatur 
Tablica 2. Zebrane parametry i uzyskane wyniki warunków ciśnienia i temperatury depozycji stałej fazy parafinowej WAT - dane eksperymentalne pierwszej serii pomiarowej

\begin{tabular}{|c|c|c|c|}
\hline $\begin{array}{c}\text { Temperatura } \\
\text { WAT }\end{array}$ & $\begin{array}{c}\text { Ciśnienie } \\
\text { nasycenia }\end{array}$ & $\begin{array}{c}\text { Ciśnienie } \\
\text { badania }\end{array}$ & \multirow{2}{*}{ Uwagi } \\
\cline { 1 - 2 }$\left[{ }^{\circ} \mathrm{C}\right]$ & {$[$ bar $]$} & {$[$ bar $]$} & \\
\hline 30,7 & 1,01 & 20 & $\begin{array}{l}\text { Badanie próbki } \\
\text { ropy martwej }\end{array}$ \\
\hline 26,5 & 50 & 70 & \\
\hline 25,3 & 100 & 120 & \\
\hline 25,5 & 150 & 170 & \\
\hline 25,9 & 200 & 220 & \\
\hline
\end{tabular}

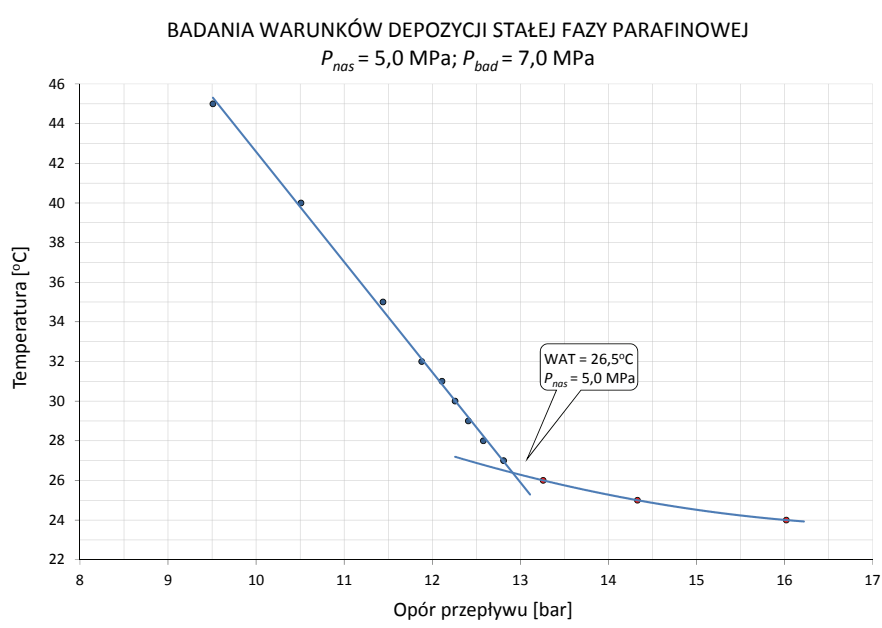

Rys. 7. Wpływ temperatury próbki ropy na opór przepływu - wyznaczenie temperatury początku depozycji stałej fazy parafinowej

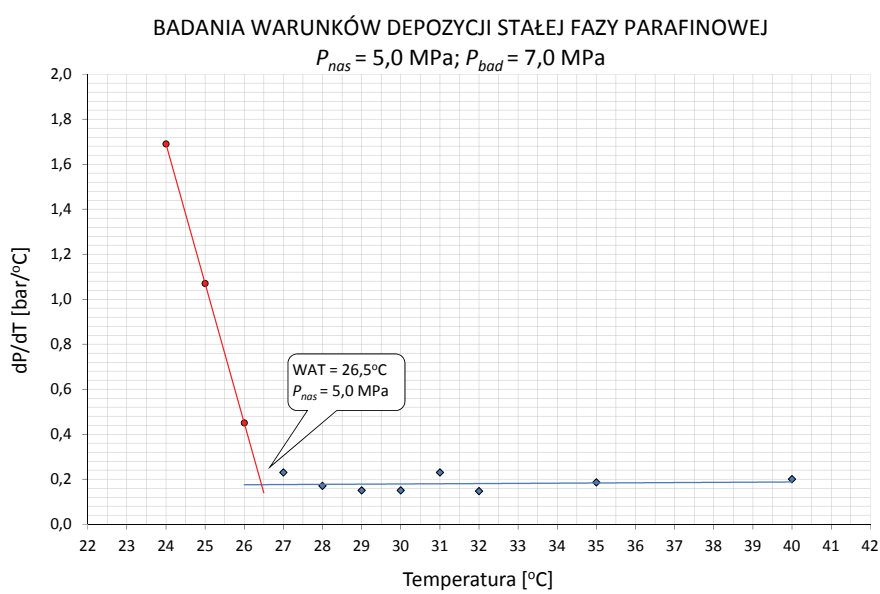

Rys. 8. Przyrost oporów przepływu przez kapilarę badanej próbki ropy w funkcji temperatury

depozycji stałej fazy parafinowej jest o $5,4^{\circ} \mathrm{C}$ niższa w porównaniu z próbką ropy martwej. Powyżej ciśnienia nasycenia 100 bar, mimo stale wzrastającej ilości rozpuszczonego gazu w próbce, zmiany wartości temperatury WAT są nieznaczne i wykazano jej powolny wzrost. Obliczona zmiana tego parametru pomiędzy ciśnieniem nasycenia próbki 100

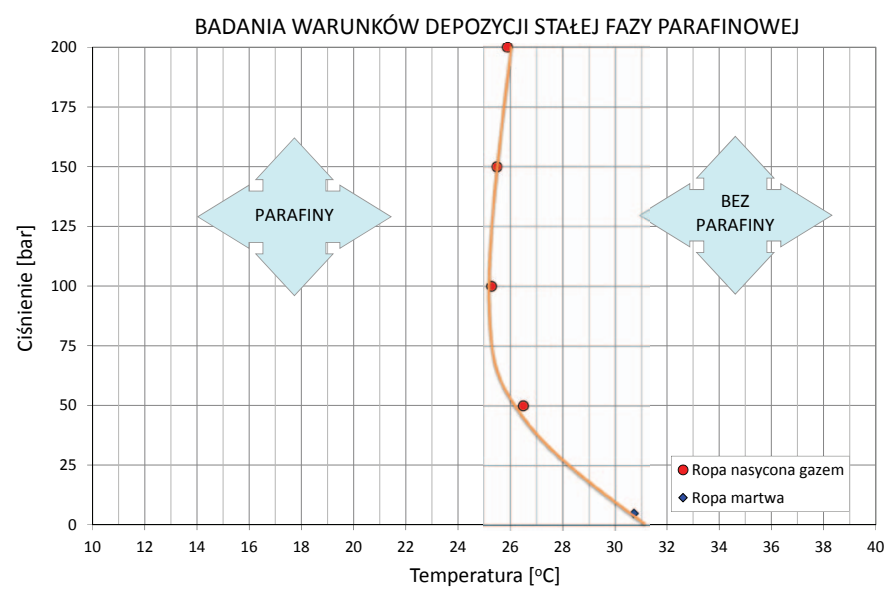

Rys. 9. Obszar PT wytrącania parafiny - wyznaczony eksperymentalnie w pierwszej serii pomiarowej dla ropy nasyconej

a 200 barów wyniosła jedynie $0,4^{\circ} \mathrm{C}$ i w tym przedziale ciśnienie i wzrastająca ilość rozpuszczonego gazu „znoszą się" wzajemnie, czyli odmiennie oddziałują na zjawisko wytrącania się parafin.

W drugiej serii badawczej przeprowadzono cztery eksperymenty. Przed każdym badaniem wykonywano rekombinację około $300 \mathrm{~cm}^{3}$ próbki do ciśnienia nasycenia 200 barów w temperaturze $45^{\circ} \mathrm{C}$.

Założono, że każdy eksperyment przeprowadzony zostanie dla próbki ropy o tej samej wartości ciśnienia nasycenia. Dla kolejnych badań próbka będzie sprężana do wyższego ciśnienia w krokach co 50 bar do uzyskania $P_{b a d}=400$ bar.

Na wykresach $10 \div 11$ przedstawiono przebieg przeprowadzonych eksperymentów (po dwa dla każdego badania). $\mathrm{Na}$ pierwszym zobrazowany został wpływ temperatury próbki ropy na opór przepływu. Na drugim zobrazowano przyrost oporów przepływu przeliczony na jeden stopień Celsjusza w funkcji temperatury. W obu przypadkach zaznaczona została wartość temperatury WAT.

W tablicy 3 zebrano główne wyniki badań, a na rysunkach 10 i 11 przedstawiono przebieg jednego z szeregu przeprowadzonych eksperymentów.

Na podstawie wyznaczonej krzywej łatwo zauważyć, że wraz ze wzrostem ciśnienia pomiaru, przy zachowaniu stałego ciśnienia nasycenia wynoszącego 200 bar, liniowo wzrasta ryzyko wytrącenia parafiny. Przyrost WAT na każde 100 bar wzrostu ciśnienia pomiaru wynosi $1,7^{\circ} \mathrm{C}$.

Badania wykonane zostały w szerokim zakresie ciśnień (od 1,01 do 400 bar) pokrywającym spadek ciśnienia w trakcie eksploatacji płynu złożowego i temperatury w zakresie od $20^{\circ} \mathrm{C}$ do $45^{\circ} \mathrm{C}$. Zebrane wyniki stanowią połączenie dwóch przeprowadzonych serii pomiarowych. Pierwsza seria eksperymentów uwzględniała zmiany ciśnienia nasycenia wraz ze wzrostem ciśnienia pomiaru; w drugiej 
uwzględniono zmiany badanego ciśnienia przy zachowaniu stałego ciśnienia nasycenia analizowanej próbki ropy. Uzyskane wyniki badań zobrazowano na rysunku 13 . Na wykresie wyznaczono krzywą „parafin” rozdzielającą obszar występowania parafiny od obszaru wolnego od parafiny $\mathrm{w}$ fazie stałej.

Tablica 3. Zebrane parametry i uzyskane wyniki warunków ciśnienia i temperatury depozycji stałej fazy parafinowej WAT - dane eksperymentalne dla drugiej serii pomiarowej

\begin{tabular}{|c|c|c|c|}
\hline Temperatura WAT & Ciśnienie nasycenia & Ciśnienie badania & \multirow{2}{*}{ Uwagi } \\
\cline { 1 - 3 }$\left[{ }^{\circ} \mathrm{C}\right]$ & {$[\mathrm{bar}]$} & {$[$ bar $]$} & \\
\hline 25,9 & 200 & 220 & \multirow{3}{*}{ Ciśnienie nasycenia mniejsze od ciśnienia badania } \\
\hline 26,8 & 200 & 250 & \multirow{2}{*}{300} \\
\cline { 1 - 3 } 27,8 & 200 & 350 & \\
\hline 28,5 & 200 & 400 & \\
\hline 29,3 & 200 & &
\end{tabular}

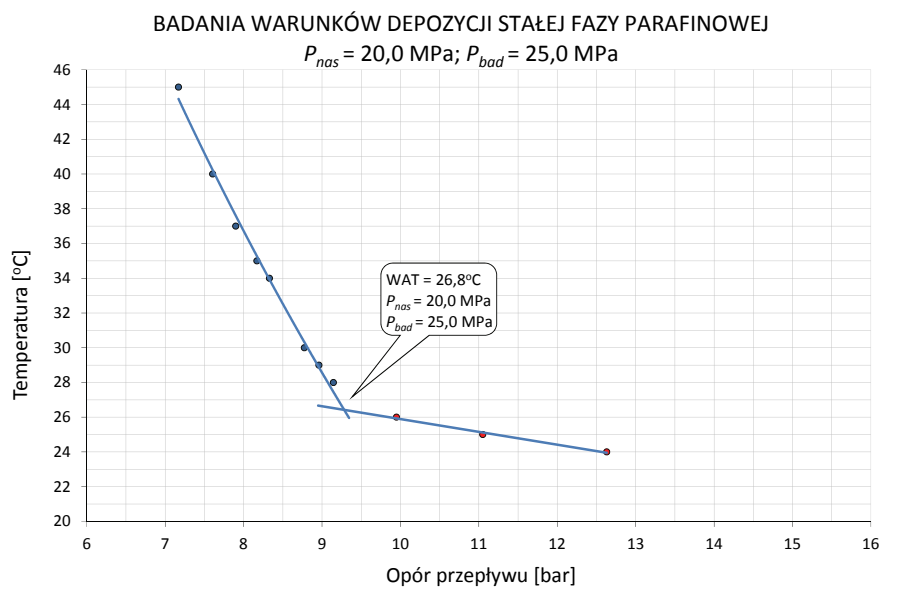

Rys. 10. Wpływ temperatury próbki ropy na opór przepływu - wyznaczenie temperatury początku depozycji stałej fazy parafinowej

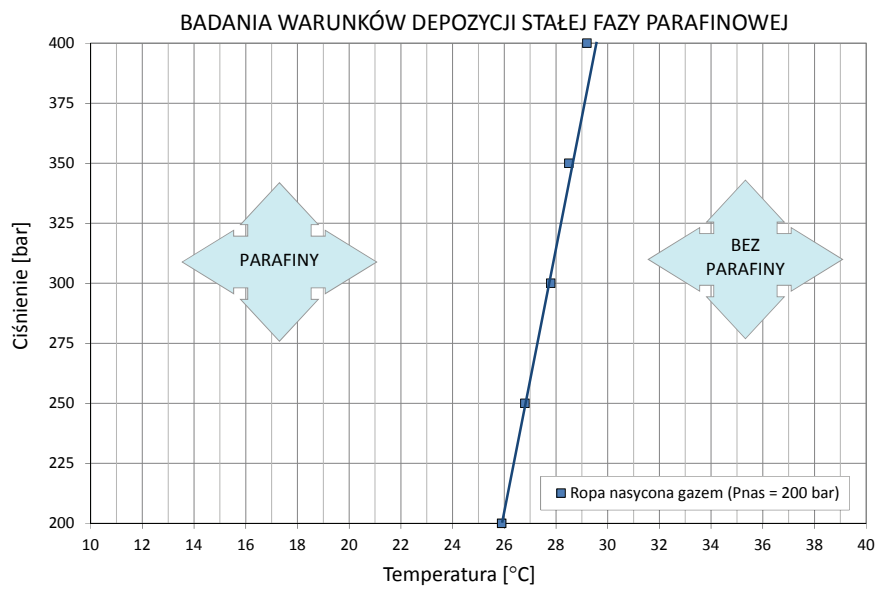

Rys. 12. Obszar PT wytrącania parafiny - wyznaczony eksperymentalnie w drugiej serii pomiarowej dla ropy nienasyconej

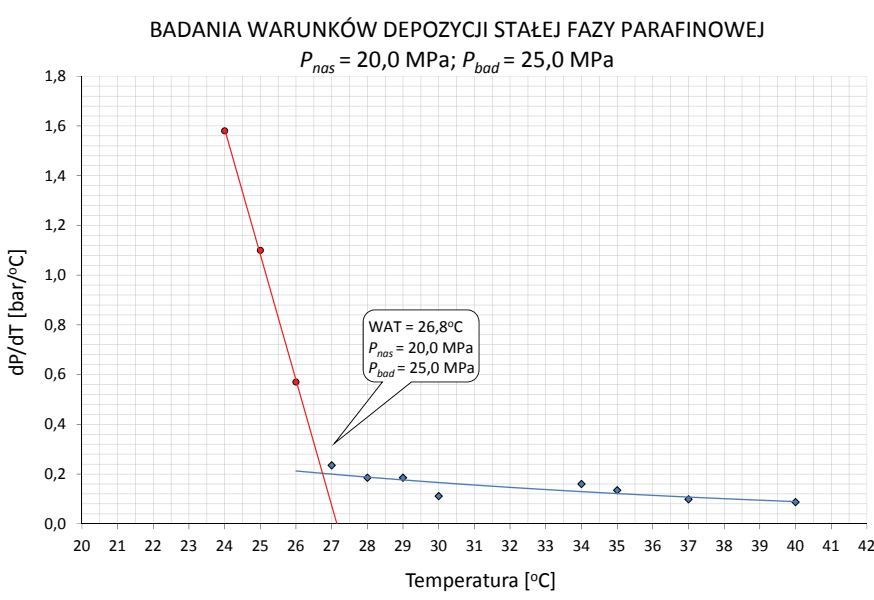

Rys. 11. Przyrost oporów przepływu przez kapilarę badanej próbki ropy w funkcji temperatury

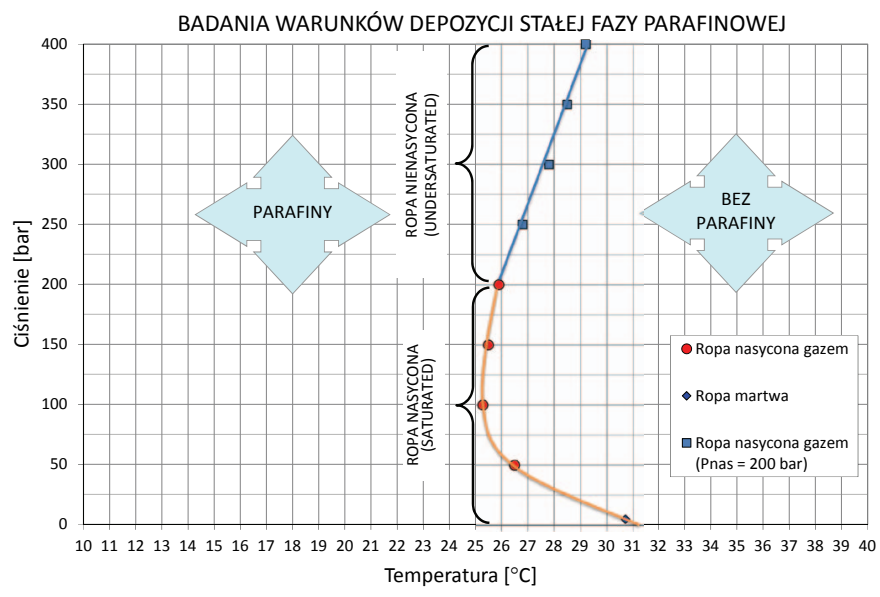

Rys. 13. Układ PT wytrącania parafiny - wyznaczony eksperymentalnie 


\section{Podsumowanie}

Dotychczas Instytut Nafty i Gazu - Państwowy Instytut Badawczy dysponował aparaturą umożliwiającą zbadanie warunków depozycji stałej fazy parafinowej jedynie dla próbki ropy martwej (ropa martwa - ropa naftowa, w której brak obecności gazu bądź lotnych węglowodorów w niej rozpuszczonych). W wyniku potrzeb rozbudowano posiadaną bezrtęciową aparaturę PVT pod kątem badań warunków depozycji stałej fazy parafinowej. Wykorzystano możliwości posiadanej aparatury do wykonania rekombinacji badanej próbki ropy do dowolnych parametrów ciśnienia i temperatury.

Opracowana metodyka wykorzystuje przyrost oporów przepływu badanej próbki ropy przez kapilarę. Proces ten ma miejsce, gdy w wyniku spadku temperatury nastąpi krystalizacja i wytworzenie parafinowej zawiesiny w ropie. W przeprowadzonych badaniach zjawisko to wykorzystuje się do identyfikacji temperatury WAT.

Ciśnienie i rozpuszczony w próbce ropy gaz ma wpływ na uzyskiwane wyniki WAT. Badania wykonane dla próbki ropy martwej dały wynik o ponad $5^{\circ} \mathrm{C}$ wyższy od otrzymanych dla próbki nasyconej gazem. Spadek ciśnienia powoduje zmniejszenie rozpuszczalności gazu w ropie i jego przejście z fazy stałej do gazowej. Skutkuje to spadkiem rozpuszczalności parafiny w cieczy węglowodorowej i w konsekwencji jej wytrącaniem. Udowodnione to zostało w przeprowadzonych seriach pomiarowych, gdzie wzrost ilości rozpuszczonego gazu dla badanej próbki ropy wpłynął na obniżenie
WAT, ale tylko do ciśnienia 100 barów. Dla wyższych ciśnień zaobserwowano większy wpływ przyrostu ciśnienia w stosunku to zwiększającej się ilości rozpuszczonego gazu. Obliczona zmiana tego parametru pomiędzy ciśnieniem nasycenia próbki 200 a 100 bar wyniosła już tylko $0,4^{\circ} \mathrm{C}$. Efekty wzrastającego ciśnienia i zwiększonej ilości rozpuszczonego w ropie gazu ,znoszą się”.

Określenie temperatury początku wytrącania parafiny z płynów złożowych w warunkach otworowych/transportowych wymagało uwzględnienia wpływu ciśnienia oraz rozpuszczonego gazu. Sprężanie ropy nienasyconej powoduje szybsze wytrącanie parafiny. Obliczono, że przy zachowaniu stałego ciśnienia nasycenia badanej próbki ropy wartość WAT wzrasta o $1,7^{\circ} \mathrm{C}$ na każde 100 bar przyrostu ciśnienia (w przypadku badanej próbki ropy).

Czynnik temperaturowy odgrywa kluczową rolę w wytrącaniu parafin, gdyż rozpuszczalność parafiny w płynach złożowych zmniejsza się wraz ze spadkiem temperatury. Szczególnie narażone na parafinowanie na naszych szerokościach geograficznych są instalacje wydobywcze i transportowe w czasie zimy oraz pod powierzchnią mórz (ze względu na panujące niskie temperatury). Zależność wytrącania parafin od temperatury ukazuje otrzymany diagram TP (rysunek 13), na którym wyznaczona została granica rozdzielająca obszar parafinowy (występowanie parafiny w fazie stałej) od obszaru bez parafiny.

Prosimy cytować jako: Nafta-Gaz 2017, nr 6, s. 395-404, DOI: 10.18668/NG.2017.06.04

Artykuł nadesłano do Redakcji 19.12.2016 r. Zatwierdzono do druku 4.04.2017 r.

Artykuł powstał na podstawie pracy statutowej pt.: Badanie wplywu ciśnienia i temperatury na proces wytracania parafin w ropie naftowej - praca INiG - PIB na zlecenie MNiSW; nr zlecenia: 22/KB/16, nr archiwalny: DK-4100-22/16.

\section{Literatura}

[1] Bęben D.: Ochrona rurociagów przed wytracaniem się parafiny z ropy naftowej. Nafta-Gaz 2014, nr 10, s. 684-689.

[2] Correra S., Fasano A., Fusi L., Primicerio M.: Modelling wax diffusion in crude oils: The cold finger device. Applied Mathematical Modelling 2006, tom 31, s. 2286-2298.

[3] Coto B., Martos C., Pena J.L., Espada J.J., Robustillo M.D.: A new method for the determination of wax percepitation from non-diluted crude oils by fractional precypitation. Fuel 2008, vol. 87, s. 2090-2094.

[4] Coutihno J.A.P., Dardion J.L.: The limitations of the cloud point measurment techniques and the influence of the oil composition on its detection. Petroleum Science and Technology 2005, vol. 23, s. 1113-1128.

[5] Dantas N.A.A., Gomes E.A.S., Barros N.E.L., Dantas T.N.C., Moura C.P.A.M.: Determination of Wax Apperance Temperature (WAT) in parrafin/solvent systems by photoelectric signal and viscosity. Brazilian Journal of Petroleum and Gas 2009, tom III, 4, s. 149-157.

[6] Elsharkawy A.M., Al-Sathhaf T.A., Fanhim M.A.: Wax deposition from Middle East crudes. Fuel 1999, vol. 79, s. 1047-1055.

[7] Fanchi J.R., Lake L.W.: Petroleum Engineering Handbook. General Engineering Chapter 9, Society of Petroleum Engineers 2007, vol. I, s. 864.

[8] Huang Z., Zheng S., Fogler S.: Wax Deposition: Experimental Characterisations, Theoretical Modeling, and Field Practices. Boca Raton, US: Taylor \& Francis, 2015.

[9] Ijeomah C.E., Dandekar A.Y., Chukwu G.A., Khataniar S., Patil S.L., Baldwin A.L.: Measurment of wax apperance temperature under simulated pipeline (dynamic) condition. Energy \& Fuels 2008, vol. 22, s. 2437-2442.

[10] Jeirani Z., Lashanizadegan A., Ayatollahi Sh., Javanmardi J.: The Possibility of Wax Formation in Gas Fields: a Case Study. Journal of Natural Gas Chemistry 2007, vol. 16, nr 3, s. $293-300$

[11] Kruka V.R., Cadena E.R., Long T.E.: Cloud point determination for crude oils. Journal of Petroleum Technology 1995, tom 47, s. 681-687. 
[12] Leontaritis K.J.: The Asphaltene and Wax Deposition Evenlopes. Fuel Science and Technology 1996, vol. 14, s. 13.

[13] Lubaś J.: Warunki depozycji stałej fazy parafinowej i sposoby jej zapobiegania podczas eksploatacji złóż ropy naftowej. Prace IGNiG 1999, nr 100.

[14] Lubaś J., Janocha A.: Zjawiska powstawania kompleksów parafinowo-hydratowych w mioceńskich odwiertach gazu ziemnego. Materiały VIII Międzynarodowej Konferencji Naukowo-Technicznej AGH, 1997.

[15] Musser B.J., Kilpatrick P.K.: Molecular Characterization of Wax Isolated from a Variety of Crude Oils. Energy \& Fuels 1998, vol. 12, s. 715-725.

[16] Pajda M., Gaździk B.: Wpływ środków powierzchniowo czynnych o działaniu dyspergujacym na właściwości fizykochemiczne i funkcjonalne inhibitorów parafin do wysokoparafinowych rop naftowych. Nafta-Gaz 2013, nr 4, s. 319-328.

[17] Parameshwar S., Ratnadip R.J., Babu M.: Prediction of Wax Deposition Using MATLAB Simulator: Case Study of ABC Field Pipeline. International Journal of Interdisciplinary Research and Innovation 2015, tom 3, s. 98-107.
[18] Pedersen K.S., Christensen P.L., Azeem J.: Phase Behavior of Petroleum Reservoir Fluids. $2^{\text {nd }}$ Edition, Boca Raton, Taylor \& Francis, 2014

[19] Pedersen K.S., Ronningsen H.P.: Influence of Wax Inhibitors on Wax Appearance Temperature, Pour Point and Viscosity of Waxy Crude Oil. Energy \& Fuels 2003, vol. 17, s. 321-328.

[20] Roehner R.M., Hanson F.V.: Determination of wax precypitation temperature and amount of precypitated solid wax versus temperature for crude oils using FT-IR spectroscopy. Energy \& Fuels 2001, vol. 15, nr 3, s. 756-763.

[21] Ronningsen H.P., Bjamdal B., Hansen A.B., Pedersen W.B. Wax precepitation from North Sea crude oils. 1. Crystallization and dissolution temperatures, and Newtonian and non-Newtonian flow properites. Energy \& Fuels 1991, vol. 5, s. 895-908.

[22] Singh P., Venkatesan R., Fogler H.S., Nagrajan N.: Formation and aging of incipient thin film wax-oil gels. AIChe Journal 2000, vol. 46, s. 1059-1074.

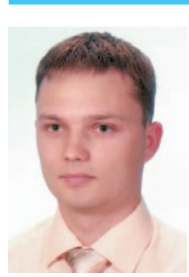

\section{Mgr inż. Sławomir SZUFLITA}

Asystent w Zakładzie Badania Złóż Ropy i Gazu. Instytut Nafty i Gazu - Państwowy Instytut Badawczy ul. Lubicz 25 A

31-503 Kraków

E-mail: slawomir.szuflita@inig.pl

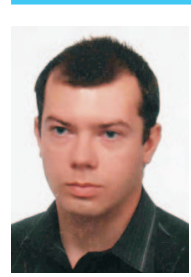

Mgr inż. Jerzy KUŚNIERCZYK

Specjalista badawczo-techniczny w Zakładzie Badania Złóż Ropy i Gazu.

Instytut Nafty i Gazu - Państwowy Instytut Badawczy ul. Lubicz 25 A

31-503 Kraków

E-mail: jerzy.kusnierczyk@inig.pl

\section{OFERTA}

\section{ZAKŁAD BADANIA ZŁÓŻ ROPY I GAZU}

Zakres działania:

- $\quad$ pobór wgłębnych i powierzchniowych próbek płynów złożowych;

- $\quad$ kompleksowe badania i analizy zmian fazowych próbek płynów złożowych na zestawie aparatów PVT firmy Chandler i Ruska;

- modelowanie procesu wypierania ropy gazem na fizycznym modelu złoża (tzw. "cienka rurka");

- pomiar lepkości ropy wiskozymetrem kulkowym lub kapilarnym w warunkach PT;

- $\quad$ optymalizacja procesów powierzchniowej separacji ropy naftowej;

- laboratoryjne i symulacyjne badania warunków wytrącania się parafin, asfaltenów w ropie oraz tworzenia się hydratów w gazie;

- badanie skuteczności działania chemicznych środków zapobiegających tworzeniu

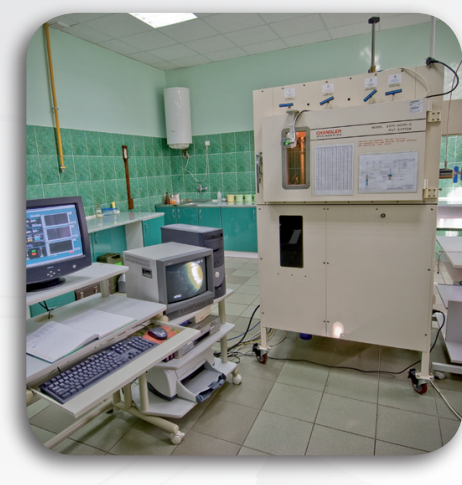
się hydratów ;

- l laboratoryjne modelowanie procesów wypierania ropy gazem w warunkach zmieszania faz;

- badanie procesów sekwestracji $\mathrm{CO}_{2}$ w solankowych poziomach wodonośnych, nasyconych gazem ziemnym;

- badania na długich rdzeniach wiertniczych dla oceny efektywności metod zwiększenia stopnia odzysku ropy.

Kierownik: dr inż. Marcin Warnecki Adres: ul. Armii Krajowej 3, 38-400 Krosno

Telefon: 134368941 w. 5226

Faks: 134367971

E-mail: marcin.warnecki@inig.pl

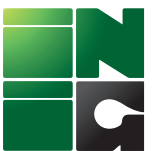

